\title{
INVESTIGATION OF VOIDAGE OF A FLUIDIZED BED OF VARIOUS SHAPES BY MODELING OF SPHERICAL PACTICLES
}

\author{
Aleš SLÍVA, Aleš PROCHÁZKA, Robert BRÁZDA \\ VSB - Technical University of Ostrava, Ostrava, Czech Republic, EU, \\ ales.sliva@vsb.cz
}

https://doi.org/10.37904/nanocon.2019.8337

\begin{abstract}
Voidage of a fluidized bed is a primary property of fluidized systems when determining the minimum floating velocity. The air flow rate in the fluidized bed (or in the fluid layer of the material) increases with diminishing bed voidage. This paper is devoted to fluidized bed voidage calculations for a fluidized bed consisting of spherical particles having different diameters and in differently shaped polygonal fluidized bed cells possessing different characteristic particle floating velocities. For testing purposes, voltage of fluidized bed was experimentally measured and subsequently modelled by simulation using the Rocky (DEM) software.
\end{abstract}

Keywords: Voidage, fluidized bed porosity, rocky

\section{INTRODUCTION}

Spherical particle arrangement for fluidization cells $[13,18]$ is a phenomenon that can be observed all around us, whether they are nanometer sized particles [5,25-28] to extremely large particles $[3,4]$. The arrangement of spherical particles can be observed in physics, chemistry, and geology, but also in mechanical engineering. Although in most practical examples the particles are stored in infinite variations in their sizes and shapes [7-11], there is a great deal of interest in the arrangement of spherical structures of the same size and shape. they are contained in different geometrically designed containers or stored in a wide range of hoppers and containers. Several different dynamic events $[1,2,12,14-17,24]$ can be observed in the spherical particle alignment process, involving several types of particle movements. These include, for example, translational movement and rotational movement $[29,30]$. The influence of the walls causes changes in these movements as well as changes in the characteristics of the arranged particles. The characteristic property of randomly deposited spherical particles in different containers is porosity [22]. Up to now, porosity has been divided into mean porosity and radial porosity distribution [18], using experiments, empirical and analytical methods [19]. Expression of average porosity is generally solved in the Ergun equation [6], which calculates the pressure drop and gas flow through an ordered particle bed $[20,21,23]$. Most porosity studies have only been performed for cylindrical vessels. The Meuller porosity method [18] analytically determines the radial distribution and mean porosity in cylindrical vessels. In this method, the spherical particles are placed particle by spherical particle in the vessel by first adding the first ball to the bottom and wall of the vessel, the next ball to the first ball and also to the wall, and this continues until the first layer of balls is formed. Another layer is then added to this layer, by placing the next ball in the most stable position, and continuing with another, etc. This particle alignment algorithm is used exclusively for spheres arranged in a cylindrical vessel, which is why this paper will deal with the mean porosity of different cell shapes.

\section{DESCRIPTION OF EXPERIMENTAL MEASUREMENT OF BED HEIGHT L AND POROSITY $\varepsilon$}

The gap determination experiment was carried out in all six vertical cells of different cross-sections, having the shape of an equilateral triangle, a square, a regular pentagon, heptagon, and a circle. Each of the above cells was filled with a batch of glass balls weighing $2 \mathrm{~kg}$. The balls were randomly poured into the cells through their 
upper part from a height of $\mathrm{Hn}=1500 \mathrm{~mm}$. The lower part of the cell had a bottom to prevent pouring out (Figure 1). The filling time was $t_{n}=10$ s so the transporting capacity of the filling is therefore $Q_{n}=0.2 \mathrm{~kg} / \mathrm{s}$.

The balls had diameters of 2,4,6,8 and $10 \mathrm{~mm}$. First, a batch of $2 \mathrm{~kg}$ of balls with a diameter $\mathrm{d}_{\mathrm{k}}=2 \mathrm{~mm}$ was measured and this batch was gradually poured into all six types of cells. After the pouring in of the whole batch, the layer height was measured.
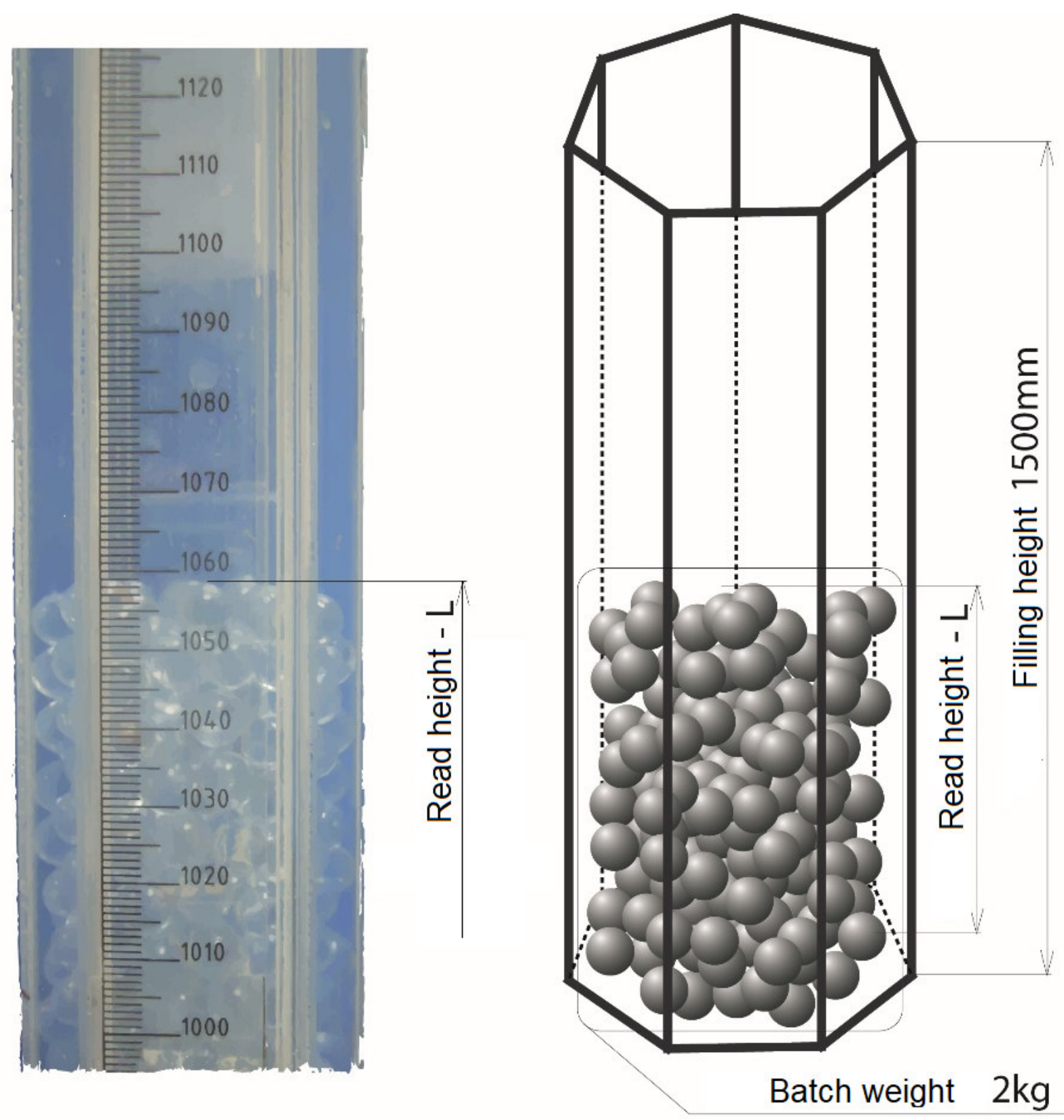

Figure 1 Example of reading the height of poured sample of balls into one of the cells $[27,28]$

The batch was subsequently poured out so that measurement could be repeated. The height of the layer was then read for each cell and batch a total of 10x These measurements were repeated for the remaining $2 \mathrm{~kg}$ batches of glass balls with diameters of $4,6,8$, and $10 \mathrm{~mm}$, and the height of layer $L$ was subtracted. The measured heights of the layers were then used to determine the porosity using the formula 
$\varepsilon=\frac{V_{0}}{V}$

where $V_{0}$ represents the volume of free space between ball filling (volume of spaces) and $V$ represents the total volume of ball filling in the cell (bed volume). The bed volume $V$ is determined from the average height of the bed $L$ and the cross-section of the bed $S$, which, as has already been mentioned, was the same for all cells.

The volume of spaces $V_{0}$ is calculated from the volume of a single ball $V_{k}$ multiplied by the number of balls $n$.

$V_{0}=1-\left(V_{k} \cdot n\right)$

The number of balls is calculated from the weight of the batch $m$ and from the weight of a single ball $m_{k}$. The weight of a single ball is determined from the volume of the ball $V_{k}$ and its density $\rho_{k}$.

$n=\frac{m}{m_{k}}$

$m_{k}=V_{k} \cdot \rho_{k}$

The volume of a ball $V_{k}$ is determined from the diameter of the ball $d_{k}$ from the known relationship:

$V_{k}=\frac{\pi \cdot d_{k}}{6}$

\section{Average porosity in cells with varied cross-section - experiment}

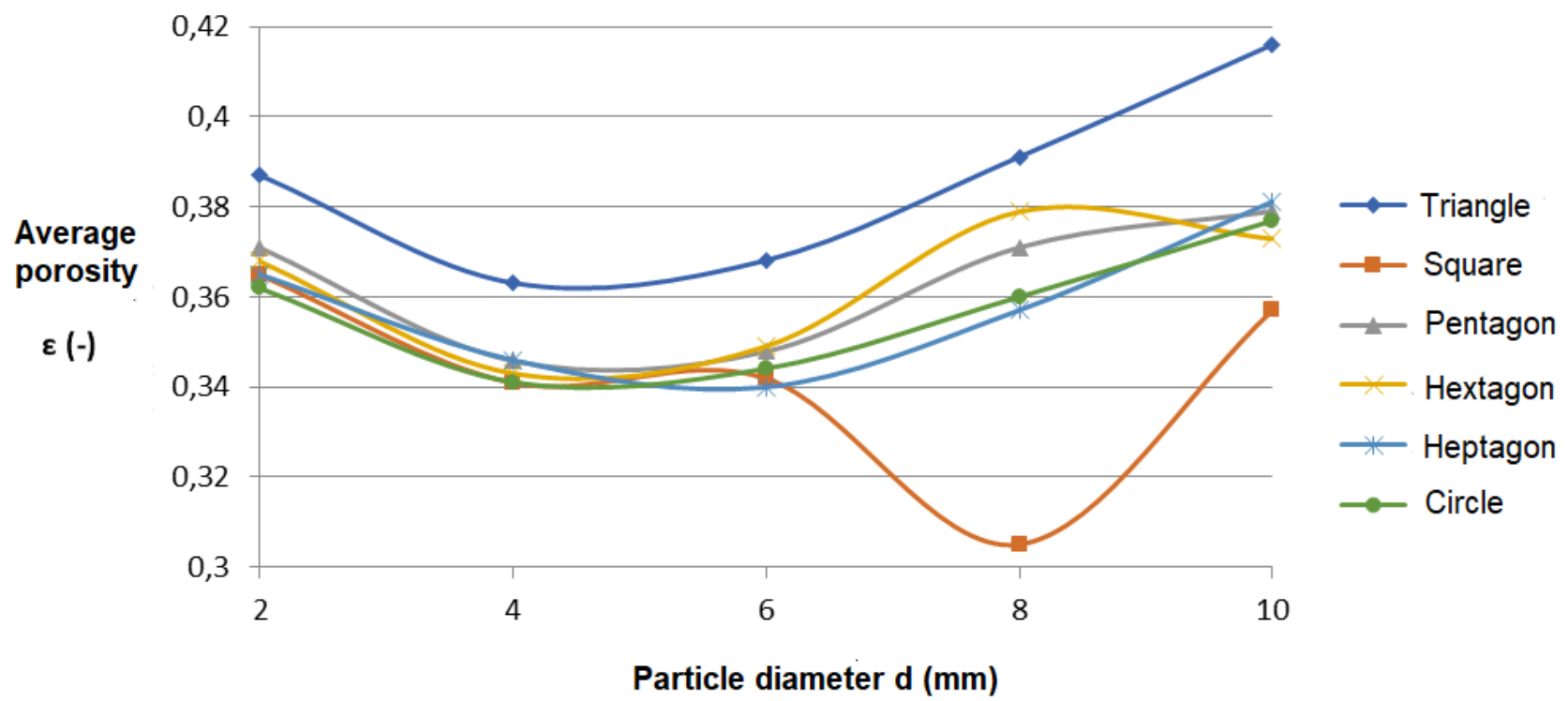

Figure 2 Average porosity in cells with varied cross-section - experiment $[27,28]$

If all of the cells studied, the largest bed height for round particles of a $2 \mathrm{~mm}$ diameter was modeled for a cell with a triangular cross-section (Figure 2, Figure 4). The smallest recorded height of a layer of ordered balls of $2 \mathrm{~mm}$ diameter was modeled on a cell with pentagonal and hexagonal cross-sections. When filling the 
examined cells with round particles with a diameter of $4 \mathrm{~mm}$, the measurement of the level of filling level in all cells showed relatively identical results.

As can be seen, for example, in Figure 3, the centers of the ordered particles are depicted as blue dots. The number of particles in the cells with a diameter of $2 \mathrm{~mm}$ is always 198947 , so when looking through the entire cell cross-section a large number of centers can then be seen, which for one overlap, but which also increasingly near the center of the cell cross-section, the more chaotic their arrangement. When filling the cells with round particles with a diameter of $4 \mathrm{~mm}$ (24 869), a more orderly (less chaotic, orderly) arrangement can be observed towards the center of the cross-section. The denser distribution of the illustrated centers of particles for round particles with a diameter of $4 \mathrm{~mm}$ than for round particles with a diameter of $6 \mathrm{~mm}$ (number 7369 ) is mainly due to the differing number of particles embedded and thus their overlap. For round particles with a diameter of $8 \mathrm{~mm}$ (3109 count), the densest distribution of the centers of the particles (and hence the particles themselves) is observed in a cell with a regular square cell cross-section (Figure 4). The number of particles in the cells with a diameter of $10 \mathrm{~mm}$ was always 1592 .

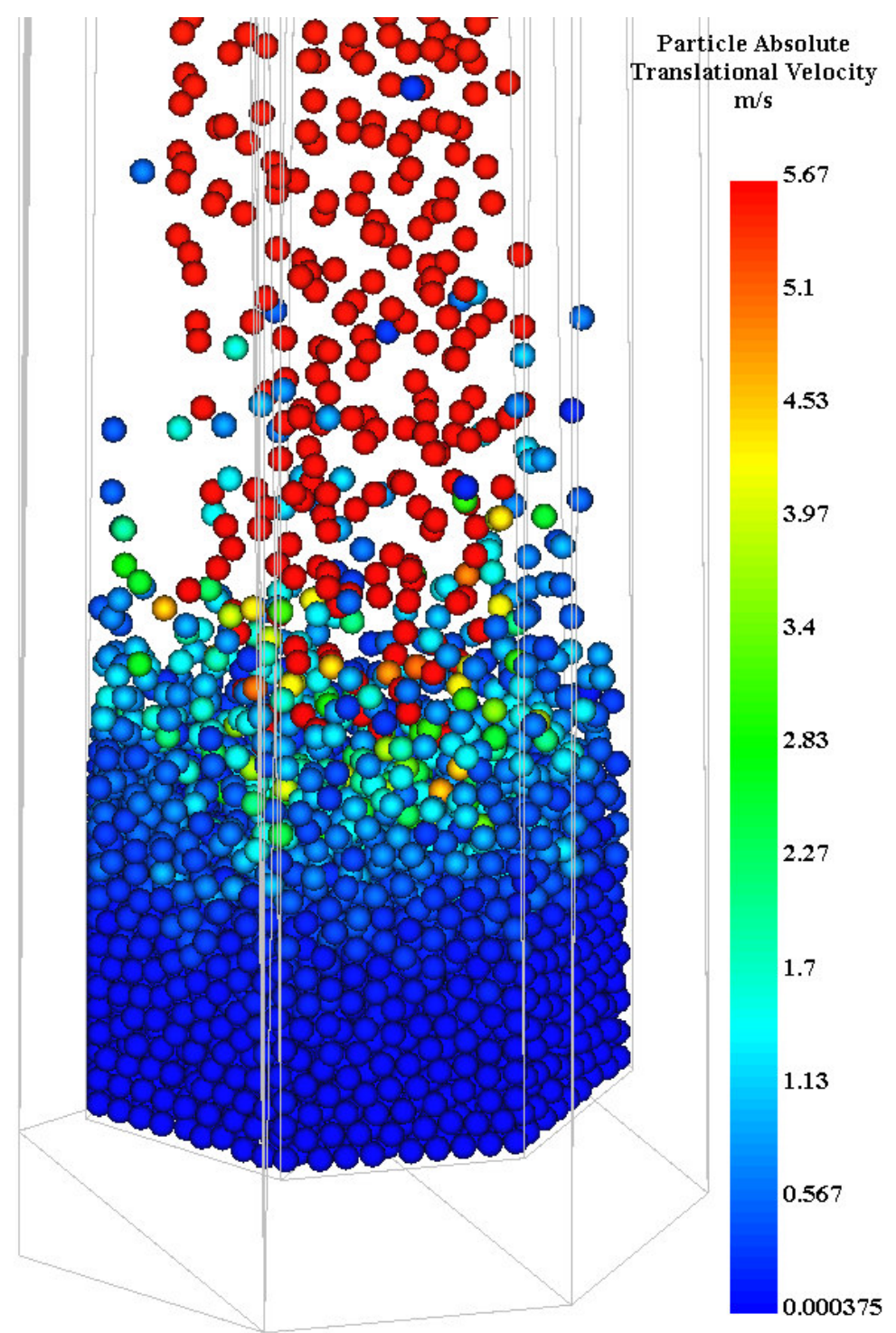

Figure 3 Example of simulation and velocity during the pouring of $2 \mathrm{~mm}$ diameter balls into a hexagonal cell $[27,28]$ 


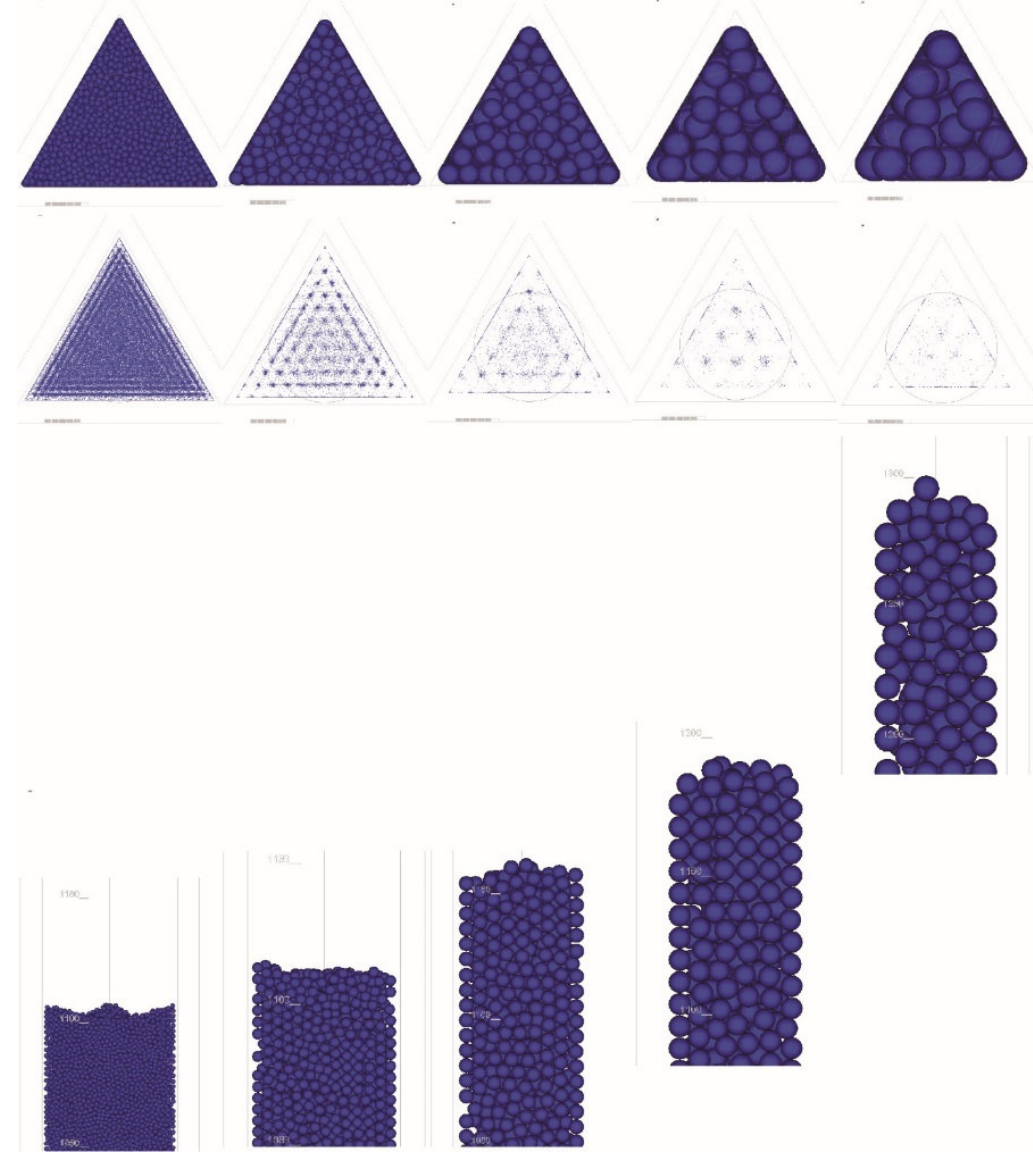

Figure 4 Modeled bed heights for a cell with a triangular layout. Top - cell view from above with whole particles depicted, middle - cell view from above with particle centers depicted, bottom - side view $[27,28]$.

\section{Average porosity in cells with varied cross-section - Rocky SW simulaion}

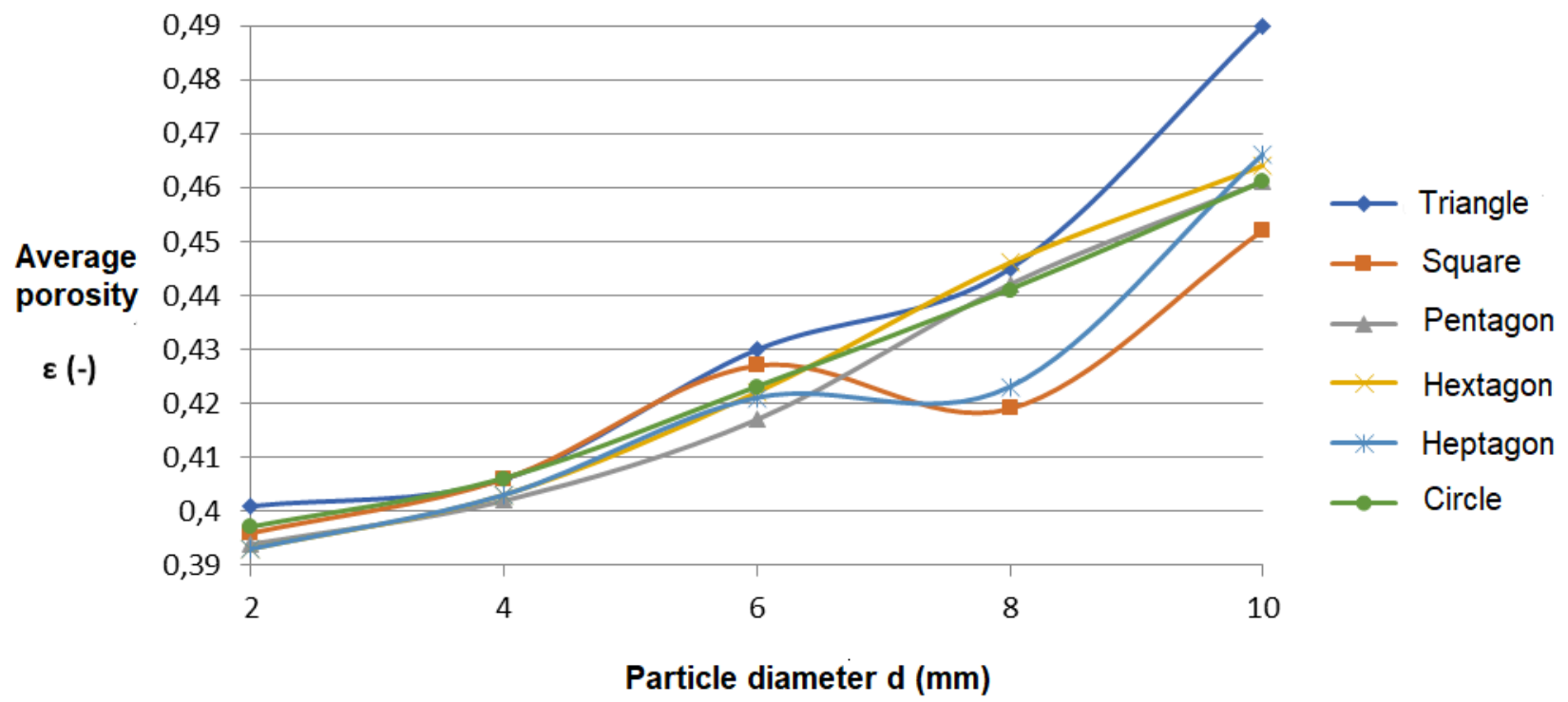

Figure 5 Average porosity in cells with varied cross-sections -Rocky SW simulation $[27,28]$ 


\section{CONCLUSION}

When validating experimental results with simulation results, several aspects that may significantly affect the results must be considered. For example, the simulation involves setting the frictional (static, dynamic) and restitution parameters between the particles and the cell wall. These may differ because, for example, the first particle that hits the bottom of the cell will have a higher impact velocity and hence a higher coefficient of restitution than the last particle that hits the highest point of the particle layer at a lower velocity. The restitution coefficient has a constant value for the simulation. In the case of dynamic friction, we cannot take into account the change of friction, for example by dust or particle contamination. The experiment is also affected by other variables, such as differing particle size in contrast to the simulation, particles have different size distribution, so it is enough that some particles are smaller, by, for example, only a tenth of a millimeter, and the resulting porosity immediately increases by several hundredths.

\section{ACKNOWLEDGEMENTS}

The paper has been prepared in connection with the Innovative and additive manufacturing technology - new technological solutions for 3D printing of metals and composite materials project, reg. no. CZ.02.1.01/0.0/0.0/17_049/0008407 financed by the Structural Founds of Europe Union and the SGS SP2019/101 Student Grant Competition - Transport Science and Research - Transport Simulation, Adhesive Models and Storage Processes project.

\section{REFERENCES}

[1] BAO, X., J., DU, W., XU, J. An Overview on the Recent Advances in Computational Fluid Dynamics Simulation of Spouted Beds. Canadian Journal of Chemical Engineering. 2013. vol. 91, iss. 11, pp. 1822-1836. https://doi.org/10.1002/cjce.21917. ISSN: 0008-4034.

[2] BOEMER, A., QI, H., RENZ, U. Verification of Eulerian simulation of spontaneous bubble formation in a fluidized bed. Chemical Engineering Science. 1998. vol. 53, iss. 10, pp. 1835+. https://doi.org/10.1016/S0009-2509(98)00044-X. ISSN: 0009-2509.

[3] BROZOVA, S. Possibility of using pyrolysis and plasma during disposal of plastic parts of electric waste. International Multidisciplinary Scientific GeoConference Surveying Geology and Mining Ecology Management, SGEM, Albena, Bulgaria, 2013, Pages 423-428. https://doi.org/10.5593/SGEM2013/BD4/S18.018. ISSN: 13142704.

[4] BROZOVA, S., DRAPALA, J., KURSA, M., PUSTEJOVSKA, P., JURSOVA, S. Leaching refuse after sphalerite mineral for extraction zinc and cobalt. Metalurgija, 2016, vol. 55, Issue 3, p. 497-499. ISSN 0543-5846.

[5] DVORSKY, R., LUNACEK, J., SLIVA, A., SANCER, J. Preparation of silicon nanoparticular nanocomposite with thin interparticular tin matrix. Journal of nanoscience and nanotechnology. 2011. Vol 11, iss. 10, pp. 9065-9071. https://doi.org/10.1166/jnn.2011.3510. ISSN: 1533-4880.

[6] ERGUN, S. Fluid flow through packed columns. Chemical Engineering Progress 48. 1952, pp.

[7] FAN, L., GRACE, J., R., EPSTEIN, N. Investigation of Nonuniformity in a Liquid-Solid Fluidized Bed with Identical Parallel Channels. AICHE JOURNAL. 2010. vol. 56, iss. 1, pp. 92-101. https://doi.org/10.1002/aic.11997. ISSN: 0001-1541.

[8] JONSTA, P., VANOVA, P., BROZOVA, S., PUSTEJOVSKA, P. Hydrogen embrittlement of welded joint made of supermartensitic stainless steel in environment containing sulfane. Archives of Metallurgy and Materials, 2016 , Vol. 61, Issue 2A, p. 709-711. https://doi.org/10.1515/amm-2016-0121. ISSN: 17333490.

[9] KARDAS, E., BROZOVA, S. Situation in waste treatment in Poland. METAL 2013 - 22nd International Conference on Metallurgy and Materials, Conference Proceedings 2013, Brno, Pages 1773-1778. ISBN: 978-808729441-3.

[10] KARDAS, E., BROZOVA, S., PUSTEJOVSKA, P. The evaluation of efficiency of the use of machine working time in the industrial company - case study. Management Systems in Production Engineering, 2017, Vol. 25, Issue 4, p. 241-245. https://doi.org/10.1515/mspe-2017-0034. ISSN: 2450-5781. 
[11] KALITA, P., SAHA, U., K., MAHANTA, P. Parametric study on the hydrodynamics and heat transfer along the riser of a pressurized circulating fluidized bed unit. Experimental Thermal and Fluid Science. 2013. vol. 44, pp. 620-630. https://doi.org/10.1016/j.expthermflusci.2012.09.001. ISSN: 0894-1777.

[12] KARMAKAR, M., K., DATTA, A., B. Hydrodynamics of a dual fluidized bed gasifier. ADVANCED POWDER TECHNOLOGY. 2010. vol. 21, iss. 5, pp. 521-528. https://doi.org/10.1016/j.apt.2010.02.001. ISSN: 0921-8831.

[13] LAUGWITZ, A., ROESSGER, P., SCHURZ, M., RICHTER, A., MEYER, B. Towards a validated CFD setup for a range of fluidized beds. Advanced Powder Technology. 2017. vol. 318, pp. 558-568. https://doi.org/10.1016/J.POWTEC.2017.06.013. ISSN: 0032-5910.

[14] LU, X., HOLLAND, D. J. Investigation of drag models for the two fluid simulation of Geldart group A powders. Advanced Powder Technology. 2016. vol. 304, pp. 41-54. https://doi.org/10.1016/J.POWTEC.2016.07.063. ISSN: 0032-5910.

[15] MA, H., XU, L., ZHAO, Y. CFD-DEM simulation of fluidization of rod-like particles in a fluidized bed. ADVANCED POWDER TECHNOLOGY. 2017. vol. 314, pp. 355-366. https://doi.org/10.1016/J.POWTEC.2016.12.008. ISSN: 0032-5910.

[16] MAKKAWI, Y., T., WRIGHT, P., C. The voidage function and effective drag force for fluidized beds. CHEMICAL ENGINEERING SCIENCE. 58, iss. 10, pp. 2035-2051. https://doi.org/10.1016/S0009-2509(03)00054-X. ISSN: 0009-2509.

[17] MALONE, K. F., XU, B. H. Particle-scale simulation of heat transfer in liquid-fluidised beds. ADVANCED POWDER TECHNOLOGY. 2008. vol. 184, iss. 2, pp. 189-204. https://doi.org/10.1016/J.POWTEC.2007.11.043. ISSN: 0032-5910.

[18] MUELLER, G. E. Numerically packing spheres in cylinders. Advanced Powder Technology. 2005. vol. 159, iss. 2, pp. 105-110. https://doi.org/10.1016/J.POWTEC.2005.06.002. ISSN: 0032-5910.

[19] OUJEZDSKY, A., SLIVA, A., BRAZDA, R. Using ICT in education: measuring systems interfaced to computers. In 9th International technology, education and development conference. Madrid: INTED Proceedings, 2015, pp. 7509-7512. ISBN:978-84-606-5763-7.

[20] PANNEERSELVAM, R., SAVITHRI, S., SURENDER, G., D. CFD based investigations on hydrodynamics and energy dissipation due to solid motion in liquid fluidised bed. CHEMICAL ENGINEERING SCIENCE. 2007. Vol. 132, iss.1-3, pp. 159-171. https://doi.org/10.1016/j.cej.2007.01.042. ISSN: 1385-8947.

[21] PUGSLEY, T., S., MILNE, B., J., BERRUTI, F. An innovative non-mechanical solids feeder for high solids mass fluxes in circulating fluidized bedrisers. Advanced Powder Technology. 1996. vol. 88, pp. 123-131. ISSN: 00325910.

[22] REICHHOLD, A., KRONBERGER, B., FRIEDL, G. Temporary defluidization in fine powder fluidized beds caused by changing the fluidizing gas. Chemical Engineering Science. 2006. vol. 61, iss. 8, pp. 2428-2436. https://doi.org/10.1016/i.ces.2005.10.054. ISSN: 0009-2509.

[23] SAIDI, M., TABRIZI, H., B., GRACE, J., R., LIM, C.J. Hydrodynamic investigation of gas-solid flow in rectangular spout-fluid bed using CFD-DEM modeling. Advanced Powder Technology. 2015. vol. 284, pp. 355-364. https://doi.org/10.1016/J.POWTEC.2015.07.005. ISSN: 0032-5910.

[24] SAXENA, S., C., SHRIVASTAVA, S. Some Hydrodynamic Investigations of a Magnetically Stabilized AirFluidized Bed Offerromagnetic Particles. Advanced Powder Technology. 1991. vol. 64, iss.1-2, pp. 57-67. ISSN: 0032-5910.

[25] SLIVA, A., BRAZDA, R., ZEGZULKA, J., DVORSKY, R., LUNACEK, J. Particle characterization of nanoparticle materials in water jet mill device. Journal of scientific conference proceedings. 2010. vol 2, iss.1, pp. 45-+. https://doi.org/10.1166/jcp.2010.1009. ISSN: 1937-6456.

[26] SLIVA, A., SAMOLEJOVA, A., BRAZDA, R., ZEGZULKA, J., POLAK, J. Optical parameter adjustment for silica nano and micro-particle size distribution measurement using mastersizer 2000. MICROWAVE AND OPTICAL TECHNOLOGY. 2003. vol. 5445, pp. 160-163. https://doi.org/10.1117/12.558761. ISBN:0-8194-5368-4.

[27] SLIVA, A., BRAZDA, R., PROCHAZKA, A., MARTYNKOVA, G., S., BARABASZOVA, K., C. Study of the optimum arrangement of spherical particles in containers having different cross section shapes. Journal of nanoscience 
and nanotechnology. 2019. vol 19, iss. 5, pp. 2717-2722. https://doi.org/10.1166/inn.2019.15873. ISSN: 15334880.

[28] SLIVA, A., BRAZDA, R., PROCHAZKA, A., MARTYNKOVA, G., S., BARABASZOVA, K., C. Investigation of geometric properties of modified titanium white by fluidisation for use in the process of transport, handling, processing and storage. Journal of nanoscience and nanotechnology. 2019. vol 19, iss. 5, pp. 2997-3001. https://doi.org/10.1166/jnn.2019.15872. ISSN: 1533-4880.

[29] STOLLHOF, M., PENTHOR, S., MAYER, K., Hofbauer, H. Estimation of the solid circulation rate in circulating fluidized bed systems. Powder Technology. 2018. vol. 336, pp. 1-11. https://doi.org/10.1016/j.powtec.2018.05.033. ISSN: 0032-5910.

[30] SUBRAMANI, H., J., BALAIYYA, M., B., M., MIRANDA, L., R. Minimum fluidization velocity at elevated temperatures for Geldart's group-B powders. Experimental Thermal and Fluid Science. 2007. vol. 32, iss. 1, pp. 166-173. https://doi.org/10.1016/j.expthermflusci.2007.03.003. ISSN: 0894-1777. 